\title{
An Investigation of the Mediator Role of School Burnout Between Academic Stress and Academic Motivation
}

\author{
Fatih Veyis ${ }^{1, *}$, İsmail Seçer ${ }^{2} \&$ Sümeyye Ulaş ${ }^{3}$ \\ ${ }^{1}$ Department of Turkish Language and Literature Education, Atatürk University, Faculty of Education, Turkey \\ ${ }^{2}$ Department of educational Sciences, Atatürk University, Faculty of Education, Turkey \\ ${ }^{3}$ Department of Child Development, University of Gümüşhane, Vocational School of Health Services, Turkey \\ ${ }^{*}$ Correspondence: Atatürk University, Faculty of Education, Yakutiye, Erzurum, Turkey. Tel: 90-44-2213-7013-167. \\ E-mail: faith.veyis@atauni.edu.tr
}

Received: November 1, 2019

Accepted: November 11, 2019 Online Published: November 20, 2019

doi:10.5430/jct.v8n4p46

URL: https://doi.org/10.5430/jct.v8n4p46

\begin{abstract}
The purpose of this study is to investigate the mediator role of school burnout between academic stress and academic motivation in high school students. In the recent years, academic stress and school burnout have been considered among the problems that affect students in many ways. The study group consists of 690 high school students studying at various high school types. Academic stress, school burnout and academic motivation scales were used to collect data. Correlation analysis and structural equation model were used for data analysis. The findings of the study showed that academic stress and school burnout significantly predicted academic motivation and that school burnout had a full mediating role between academic stress and academic motivation. As a result, it is considered that school burnout is an important risk factor for students who have experienced academic stress and it is necessary to include the mediator role of school burnout in the studies aimed at reducing academic stress and improving motivation. The findings obtained from the research were discussed in line with the literature.
\end{abstract}

Keywords: Stress, academic stress, academic motivation, mediation relationship

\section{Introduction}

High school years include the academic processes such as preparing students for university education and university entrance exam and making career decisions, as well as coping with developmental problems of adolescence and preparing for adulthood. Effective overcoming of each of these processes requires significant motivation. However, considering the quality of the processes experienced during this period, it can be said that there are many negativities that may affect students' motivation. Considering the fact that high school years coincide with adolescence period, the intensity of academic duties and responsibilities to be fulfilled during this period and also the processes of preparing for adulthood and profession, there are many factors that compel students psychologically. Each of these factors is thought to trigger stressful situations that compel students psychologically (Seçer, 2015a, 2015b).

Stress is defined by Menaga and Chandrasekaran (2013) as a form of reaction that evokes negative thoughts and feelings in the face of changes or difficulties. Lazarus (1996) describes stress as the reactions of the individual in situations that are perceived as compelling and threatening in daily life. School life, exams, fear of failure, unrealistic career expectations of teachers, parents and students themselves, poor and negative relationships with peers and teachers, and the process of preparing for adulthood can all be said to be significant stress factors for students. Dedeyn, Cornelissen, Bardgett (2008) defined the mental and emotional pressure arising from the intense demands of school life as the source of academic stress in students. However, Menaga and Chandrasekaran, (2013) and Sedere (2010) argue that there is a certain level of stress that motivates students academically. None the less, considering the developmental processes related to high school years including adolescence, it is unlikely to say that the students are competent in stress management. Therefore, the stress that is thought to be caused by the effects of internal and external factors can have personal as well as academic results on students (Seçer, 2015b). In this sense, MacGeorge, Samter, Gillihan(2005), argue that stress above a certain level is commonly associated with depressive and 
psychosomatic symptoms in students and this situation negatively affects their academic experiences and especially their motivation levels. When the literature is examined, it is seen that there are studies showing the significant negative effect of stress on motivation (Gruetzmacher \& Raufelder 2019). Therefore, it is considered that academic stress can be an important risk source on academic motivation in students.

Besides, it is considered that there may be some personal factors determining the effect of academic stress on students' motivation levels. These personal factors include school burnout, which has become an important subject of study, particularly in terms of academic processes. Burnout, which is known as a concept specific to business life, has started to be mentioned and examined with the students in the recent years due to the similarity of student activities with the activities of an employee (Salmala-Aro et al., 2009; Seçer, 2013). Faced with intensive and continuous academic tasks and responsibilities from an early age, children have to overcome these processes and developmental difficulties. It is thought that adding the students', parents' and teachers' excessive demands and expectations to the academic and developmental difficulties triggers the emergence of some psychological, mental and physical symptoms in children (Salmela-Aro et al., 2009; Vasalampi, Salmela-Aro \& Nurmi, 2009). These symptoms, which are considered as school burnout, become evident in children in terms of weariness, depersonalization and doubting their competence (Salmela-Aro, Kiuru, Leskinen, \& Nurmi, 2009; Salmela-Aro, Kiuru, \& Nurmi, 2008). Studies on school burnout reveal that this negativity can affect students in many ways. In this sense, the negative consequences of school burnout are absenteeism and ditching the class (Aypay, 2012), decrease in motivation and academic achievement (Maslach \& Goldberg, 1998; Akpınar, 2016), alienation from school (Polat \& Özdemir, 2018), underestimating personal competencies and success ( Eker, 2007) and showing psychological adaptation problems (Seçer, 2015a). Based on these research findings, it can be said that school burnout is a negativity that can affect students in many ways.

However, although limited, the data related to the literature suggests that there may be a linear relationship between academic stress, school burnout and academic motivation. Based on the results of the study by Cole, Peeke, Dolezal, Murray and Canzoniero, (1999) and Seçer (2015b) that revealed academic stress is an important risk factor for school burnout in students and the study by Seçer (2015b) which revealed the negative effect of school burnout on academic motivation, it is considered that school burnout provides an environment for greater pressure on the academic motivation of students experiencing stress. In other words, the negative impact of students' stress on their academic motivations can be shaped by the experience of school burnout, and it is considered that school burnout may lead to a further decrease in motivation among students experiencing stress. These theoretical networks of variables evoke mediation relationships. Mediation relationships are defined as the existence of a third variable that shapes the relationships between dependent and independent variables (Seçer, 2015a; Seçer, 2015b).

In this context, examining the mediator role of school burnout in the relationship between academic stress and academic motivation is the main motivation source of this study. This study is limited to the measurement tools used, the working group and the variables used. It is thought that by examining the mediator role of school burnout, this study will contribute to the basic and applied researches about student life and knowledge about the negative effects of school burnout on the students and thus, it will shed light on preventive and rehabilitative studies. In this context, the basic question sought in the research process is;

Is academic stress a significant predictor of academic motivation, and does school burnout have a mediating role in this relationship?

\section{Method}

\subsection{Research Design and Tested Models}

This research is a descriptive study in relational survey model. Correlational survey studies can be defined as the studies aiming to determine whether a change in a variable or variables causes any change in the other variables that are thought to be related to (Mertens, 2019). In the research process, the predictive and mediator relationships between academic stress, school burnout and academic motivation were examined using implicit variables and structural equation modeling. Accordingly, the models tested in the research process are given below.

Model 1. Does academic stress significantly predict academic motivation?

Model 2. Does school burnout have a predictive mediator role between academic stress and academic motivation?

\subsection{Sampling Procedures and Study Group}

The study was carried out with the students studying in secondary education institutions in Erzurum city center in 
2016-2017 academic year. The population of the study was calculated to be 20,000 and it was calculated that 643 people should be reached within the $99 \%$ confidence interval. In this context, 730 people were reached by using cluster sampling and appropriate sampling methods, and scales were applied on the sample. As a result of normality and extreme value analysis, it was determined that the data of 690 people were suitable for the analysis. In the research, schools were divided into clusters as science, social sciences high schools, Anatolian high schools and vocational high schools, and sample selection process was applied. The study group consisted of 360 males and 330 females.

\subsection{Data Collection Tools}

Education Stress Scale: Developed by Sun, Dunne, Hou, and Xu (2011) and adapted into Turkish by Seçer et al. (2013), is a likert type measurement tool based on self-report. At the end of the adaptation process, it was found that the structure of the scale consisting of 16 items and 5 sub-dimensions was preserved in Turkish culture as in the original form of the scale. The fit index values for the five-factor structure were determined as (RMSEA: .060, GFI: .96, CFI: .93, NFI.. 92, IFI..92). The internal consistency coefficient of the scale was .81 and the two half reliability coefficients were .79. Factors included in the scale were pressure from study, workload, success anxiety, self-expectation and despondency. The high scores of the scale indicate the high level of academic stress.

School Burnout Scale: Developed by Salmela-Aro et al. (2009) and adapted into Turkish culture by Seçer et al. (2013). The scale is a 5-point Likert-type self-report instrument consisting of 10 items and three sub-dimensions in its original form. At the end of the adaptation process, as in the original form of the scale, it was found that $63.25 \%$ of the variance was explained in three sub-dimensions; emotional burnout, depersonalization and low personal success perception, and the model fit of this three-factor structure was found to be good ( RMSEA; .06, CFI;.94, TLI.93). The internal consistency coefficient of the scale was .87 and test-retest reliability was .88 . The high scores of the scale indicate high school burnout.

Academic Motivation Scale: is a self-report based likert-type measurement tool developed by Bozanoğlu (2004) to determine the individual differences in academic motivation levels of high school students. The scale consists of 53 items explaining $42.2 \%$ of the total variance and three sub-dimensions. The model fit indexes related to the five-factor structure of the scale were also found to be good (REMSEA: .071, RMR: .066, SRMR= .67, CFI: .92,


The sub-dimensions in the scale are as follows; self-transcendence, using knowledge and discovery. The higher scores from the scale indicate higher motivation level.

\subsection{Data Analysis and Processing}

Data collection was carried out by the researchers during the research process. Scales were applied to 730 people in total, but it was decided to exclude the data from the data set because it was determined that the data of 32 people had extreme value and the data of 8 people had significant loss value during the testing of the normality and homogeneity of the data set. After the extracted data, analyzes were performed with the data of the remaining 690 people. In order to examine the parametric conditions of the data set, normality analyzes, and extreme value analyzes were performed and it was determined that the data set had multivariate normal distribution and homogeneity and provided the basic conditions of the structural equation model.

\section{Findings and Results}

\subsection{Findings related to Relationships Between Variables and Path Diagram of the Confirmatory Measurement Model}

The key question sought in the study is that is there a significant relationship between academic stress and academic motivation in high school students, and does school burnout play a mediating role in this relationship? Correlation analysis and structural equation model with implicit variable were used to seek answer to this research question.

Table 1. Relationships Between Variables

\begin{tabular}{lcccccc}
\hline & Emot. Burn. & Depers. & Low Suc. & Motive 1 & Motive 2 & Motive 3 \\
\hline Pressure from study & $.311^{* *}$ & $.260^{* *}$ & $.350^{* *}$ & $-.10^{*}$ & $-.21^{*}$ & $-.14^{*}$ \\
Workload & $.337^{*}$ & $.276^{* *}$ & $.179^{* *}$ & $-.108^{*}$ & $-.134^{*}$ & $-.114^{*}$ \\
Excessive self-expectation & $.243^{* *}$ & $.185^{* *}$ & $.179^{* *}$ & $.245^{* *}$ & $.204^{* *}$ & $.184^{* *}$ \\
Success anxiety & $.426^{* *}$ & $.342^{* *}$ & $.460^{* *}$ & $-.139^{*}$ & $-.109^{*}$ & $-.98^{*}$ \\
\hline
\end{tabular}


When Table 1 is examined, it is seen that there are significant relationships between sub-dimensions of academic stress and school burnout and academic motivation. Based on the fact that significant relationships were determined as a result of the correlation analysis, the measurement model was built and tested before determining the predictive and mediator relationships between the variables, and the findings obtained are given in Figure 1.

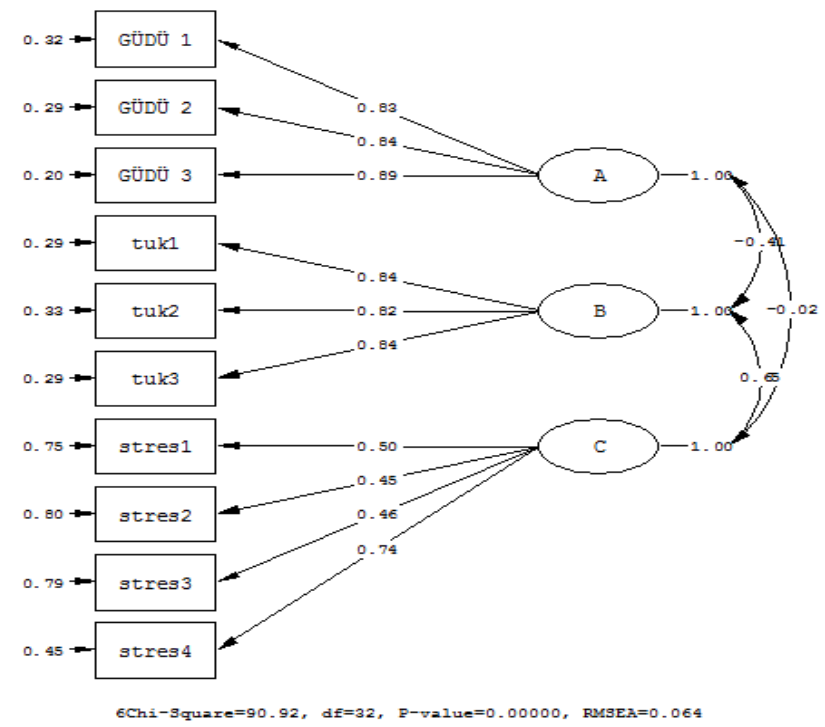

Figure 1. Path Diagram of the Confirmatory Measurement Model

Table 2. Measurement Model Goodness of Fit Indices

\begin{tabular}{lllllllllll}
\hline$\chi^{2}$ & $\mathrm{Sd}$ & $\chi^{2} / \mathrm{Sd}$ & AGFI & GFI & NFI & RFI & CFI & IFI & RMR & REMSEA \\
\hline 90,92 & 32 & 2,84 & .94 & .97 & .98 & .97 & .97 & .98 & .061 & .064 \\
\hline
\end{tabular}

When Figure 1 and Table 2 are examined, it is seen that the confirmatory measurement model established between academic stress, academic stress and school burnout fits well. After the validation of the measurement model, the Structural Equation Model was established and tested to determine the predictive relationships between variables, which is the main question of the research. The models tested in the research process are as follows.

\subsection{Findings related to Structural Equation Models}

Two different models were designed and tested during the research process. Findings for each model are given below.

Model 1. Is academic stress a significant predictor of academic motivation?

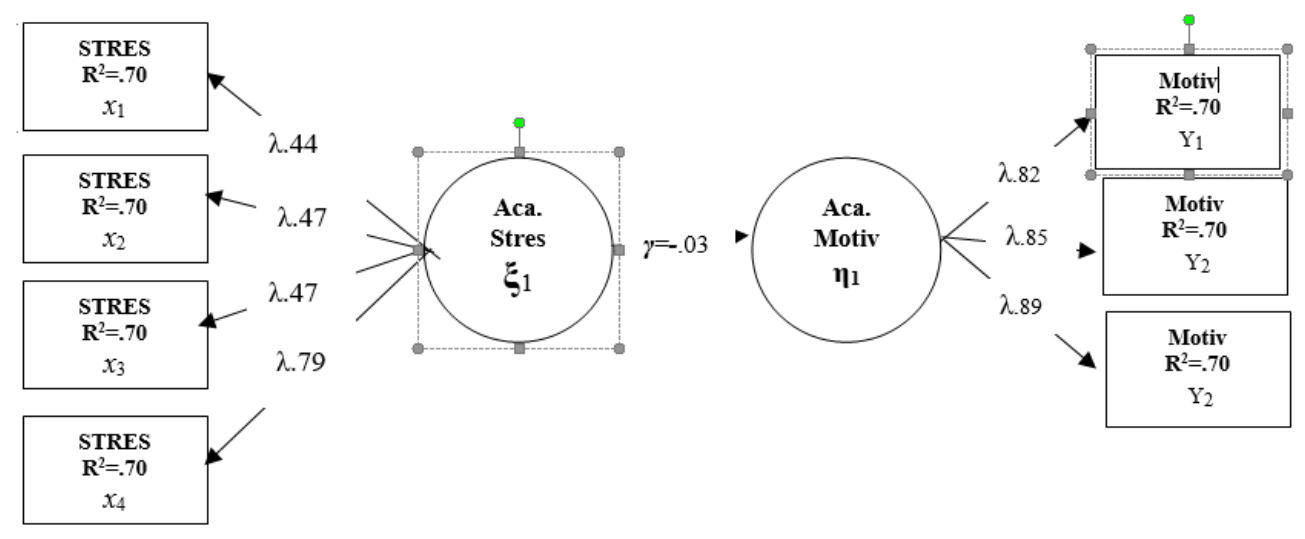

Figure 2. Structural Equation Model Showing the Relationship Between Academic Stress and Academic Motivation 
Figure 2 shows the findings of Model 1. The goodness of fit indices of the model obtained are given in Table 3.

Table 3. Goodness of Fit Indices for Model 1

\begin{tabular}{llllllllllc}
\hline$\chi^{2}$ & Sd & $\chi^{2} / \mathrm{Sd}$ & AGFI & GFI & NFI & RFI & CFI & IFI & RMR & REMSEA \\
\hline 43,41 & 13 & 2,44 & .81 & .90 & .89 & .90 & .88 & .88 & .094 & .095 \\
\hline
\end{tabular}

When Figure 2 and Table 3 are examined, it is seen that the model tested for Model 1 does not fit well. This finding can be considered that academic stress does not have a predictive effect on academic motivation. However, it can be said that this finding contradicts the literature in general. The related literature indicates that there is a negative relationship between these two variables. Accordingly, it was evaluated that there would be a third variable regulating the relationship between these two variables and the model was re-observed by including school burnout. The findings related to the structural model established as Model 2 are given in Figure 3.

Model 2. Does it have a predictive mediator role between academic stress and academic motivation?



Figure 3. Structural Equation Model Showing the Mediator Role of School Burnout Between Academic Stress and Academic Motivation

Figure 3 shows the findings of Model 2, which was constructed during the research process. The goodness of fit indices of the model obtained are given in Table 4.

Table 4. Goodness of Fit Indices for Model 2

\begin{tabular}{llllllllllc}
\hline$\chi^{2}$ & Sd & $\chi^{2} /$ Sd & AGFI & GFI & NFI & RFI & CFI & IFI & RMR & REMSEA \\
\hline 88,25 & 32 & 2,75 & .87 & .92 & .92 & .90 & .95 & .95 & .071 & .073 \\
\hline
\end{tabular}

When Table 4 is examined, it can be said that the fit indices of the model related to the mediation of school burnout between academic stress and academic motivation are sufficient according to generally accepted criteria and that the mediation model is validated. (Hu \& Bentler, 1999; Marcoulides \& Schumacher 2001; Schumacher \& Lomax 2004). According to these obtained findings, it can be said that school burnout has a full mediating role between academic stress and academic motivation.

\subsubsection{Coefficients of Determination Related to Structural Equation Model}

The coefficients of determination indicate how much the academic stress and school burnout, the predictor variables, explain the variance in academic motivation, the predicted variable. In this context, the findings regarding the 
explanatory coefficients of the predictive variables are given in Table 5 below.

Table 5. SEM Coefficients of Determinations

\begin{tabular}{lc}
\hline Fit parameter & Coefficient value \\
\hline $\mathrm{X}_{1:}$ Academic stress 1 & .23 \\
$\mathrm{X}_{2: \text { Academic Stress 2 }}$ & .23 \\
$\mathrm{X}_{\text {3: Academic Stress 3 }}$ & .17 \\
$\mathrm{X}_{\text {3: Academic Stress 4 }}$ & .59 \\
$\mathrm{Y}_{\text {1: Emotional Exhaustion }}$ & .70 \\
$\mathrm{Y}_{\text {1: Depersonalization }}$ & .68 \\
$\mathrm{Y}_{\text {1: Low Success Perception }}$ & .70 \\
$\mathrm{Y}_{\text {1: Motivation 1 }}$ & .67 \\
$\mathrm{Y}_{2 \text { Motivation 2 }}$ & .70 \\
$Y_{3 \text { Motivation 3 }}$ & .81 \\
$\xi_{1:} \eta_{1}$ & .40 \\
$\xi_{1:} \eta_{2}$ & .16 \\
\hline
\end{tabular}

When Table 5 is examined, it is seen that academic stress explains $40 \%$ of the variance in school burnout and school burnout explains $16 \%$ of the variance in academic motivation. In the measurement models, the academic stress implicit variable explains the variance in its indicator variables as $23 \%$ in dimension 1 and dimension $2,17 \%$ in dimension 3 and $59 \%$ in dimension 4 , respectively. The implicit variable of school burnout explains $70 \%$ of the variance in indicator variables, $70 \%$ of emotional exhaustion, $68 \%$ of depersonalization and $70 \%$ of low personal accomplishment. The implicit variable of academic motivation explains $67 \%$ of variance in dimension $1,70 \%$ of variance in dimension 2 , and $80 \%$ of variance in dimension 3.

3.2.2 Total and Indirect Effects on Mediator Model

The total and indirect effects of academic stress and school burnout on academic motivation are shown in Table 6.

Table 6. Total and Indirect Effects

\begin{tabular}{lccc}
\hline & \multicolumn{2}{c}{ Total Effect } & Indirect Effect \\
\hline Stress 1 & Academic Stress & School Burnout & Academic Motivation \\
Stress 2 & .51 & & \\
Stress 3 & .51 & & \\
Stress 4 & .42 & & .21 \\
Emotional Exha. & .75 & .87 & .21 \\
Depersonalization & .43 & .84 & .17 \\
Low success perc. & .43 & .86 & .20 \\
Motive 1 & .35 & .31 & .20 \\
Motive 2 & .23 & .32 & .27 \\
Motive 3 & .23 & .38 & \\
\hline
\end{tabular}

When Table 6 is examined, it is seen that academic stress implicit variable directly affects school burnout and school burnout directly affects motivation. However, it is seen that the academic stress variable indirectly predicts academic motivation through school burnout.

\section{Discussion and Conclusion}

In this research process, it was investigated whether school burnout, which has become an important field of study in academia in recent years, has a predictive role in the relationship between academic stress and academic motivation. Academic stress is the inevitable result of student life and activities (Seçer, 2015a). Since both the intensity of 
academic processes and the expectations of the student's own and his / her environment and the competency perceptions of meeting these expectations can be important sources of stress.

However, although it is suggested that the presence of stress at a certain level is a driving force for students, some psychological and academic results are inevitable for students who fail to manage stress due to developmental processes (Seçer, 2015b). One of the focal points of this study is the expectation that academic motivation may fall among the possible negative results.

However, as in many aspects, external variables that shape the relationship between academic stress and academic motivation are theoretically evaluated, and in this context, the mediator role of school burnout, which is determined to have a linear relationship with both concepts in the literature review (Seçer, 2015a; Seçer, 2015b) is examined.

The findings of the study showed that there is no direct significant relationship between academic stress and academic motivation, and that the predictor relationships emerge between the two variables when the school burnout variable is included as a mediating variable in the structural equality model. In other words, a student's level of academic stress is a major threat to her academic motivation, but only if s/he experiences school burnout. It can be considered that a possible school burnout situation in students paves the way for factors such as stress, etc. to create more pressure on motivation. This statement contradicts the views of McGeorge et al. (2005) who argue that stress has a negative effect on motivation. This contradiction is thought to have two different sources. First, it is possible that the results of the research will vary depending on the differences of the samples studied and second, the possibility of the second type of error being involved in the research results. When these two views are considered, it is seen that they directly deal with the relationships between stress and motivation and do not focus on alternative explanations by ignoring the third (external) variables. This situation may cause question marks about the internal validity of these researches and make the findings suspicious (Mertens, 2019). In this study, school burnout was included as a mediating variable and structural equality model was used as an analysis technique. With these two processes, it was possible to reduce the second type of error and thus the internal validity of the study increased (Mertens, 2019; Field, 2009). Therefore, it can be said that the potential negative impact of academic stress on motivation is highly dependent on school burnout and that stress can become an important pressure factor on students who show signs of school burnout. This is in line with the results of the studies (Aypay, 2012; Polat \& Özdemir, 2018; Cole, et al., 1999) which show the negative effects of school burnout and academic stress on students.

In conclusion, it is thought that the importance of school burnout should be considered to be a risk factor for students experiencing academic stress and it is considered an inevitable necessity to involve the intermediary role of school burnout in the applied studies and the basic researches that intend to both increase motivation and reduce stress.

As a result, it is useful to consider the importance of school burnout as a risk factor in students experiencing academic stress and finally, it is worth mentioning the limitations of the results of this study. The fact that this study was conducted only with high school students constitutes an important limitation. It is thought that conducting similar broad-based studies including all teaching levels will increase the validity of the findings obtained related to school burnout in the research process. In addition, it is considered that conducting meta-synthesis studies on similar studies both at national and international level is scientifically beneficial in revealing research tendencies in this direction and in making researches on the academic problems faced by students.

\section{References}

Akpınar, M. (2016). Okul tükenmişliği ile akademik stres ve öznel iyi oluş arasındaki ilişkinin incelenmesi. Yüksek Lisans Tezi, Atatürk Üniversitesi, Eğitim Bilimleri Enstitüsü.

Aypay, A. (2012). Ortaöğretim öğrencileri için okul tükenmişliği ölçeği (OOTÖ). Kuram ve Uygulamada Eğitim Bilimleri, 12(2), 773-787.

Bozanoğlu, İ. (2004). Akademik güdülenme ölçeği: Geliştirmesi, geçerliği, güvenirliği. Ankara Üniversitesi Eğitim Bilimleri Fakültesi Dergisi, 37(2), 83-98. https://doi.org/10.1501/Egifak_0000000094

Cole, D. A., Peeke, L., Dolezal, S., Murray, N., \& Canzoniero, A. (1999). A longitudinal study of negative affect and self-perceived competence in young adolescents. Journal of Personality and Social Psychology, 77(4), 851-862. https://doi.org/10.1037/0022-3514.77.4.851

De Deyn, G. B., Cornelissen, J. H., \& Bardgett, R. D. (2008). Plant functional traits and soil carbon sequestration in contrasting biomes. Ecology letters, 11(5), 516-531. https://doi.org/10.1111/j.1461-0248.2008.01164.x 
Grützmacher, L., \& Raufelder, D. (2019). Empirische Arbeit: Das reziproke Zusammenspiel von Stresserleben, sozialen Beziehungen mit Peers und Lehrkräften und schulischer Leistung im Verlauf von früher zu mittlerer Adoleszenz. Psychologie in Erziehung und Unterricht, 66(2), 118-130. https://doi.org/10.2378/peu2019.art11d

Hu, L. T., \& Bentler, P. M. (1999). Cutoff criteria for fit indexes in covariance structural analysis: Conventionalcriteria versus new alternatives. Structural Equation Modeling, 6(1), 55-65. https://doi.org/10.1080/10705519909540118

Lazarus, R. S. (1993). From psychological stress to the emotions. Annual Review of Psychology, 44, 1-21. https://doi.org/10.1146/annurev.ps.44.020193.000245

MacGeorge, E. L., Samter, W., \& Gillihan, S. J. (2005). Academic stress, supportive communication, and health. Communication Education, 54(4), 365-372. https://doi.org/10.1080/03634520500442236

Marcoulides, G., \& Schumacher, R. (2001). New developments and Techniques in structural Equatıon modeling. London: Lawrence Erlbaum Associates, Publishers. https://doi.org/10.4324/9781410601858

Maslach, C., \& Goldberg, J. (1998). Prevention of burnout: New perspectives. Applied and preventive psychology, 7(1), 63-74. https://doi.org/10.1016/S0962-1849(98)80022-X

Menaga, S., \& Chandrasekaran, V. (2014). A study on academic stress of higher secondary school students. Scholarly Research Journal for Interdisciplinary Studies, 2(14), 1973-1981.

Mertens, D. M. (2019). Research and evaluation in education and psychology: Integrating diversity with quantitative, qualitative, and mixed methods. Sage Publications.

Polat, Ş., \& Özdemir, M. (2018). Ortaokul Öğrencilerindeki Eğitim Stresi, Okul Tükenmişliği ve Okula Yabancılaşma Arasındaki İlişkilerin İncelenmesi. Kastamonu Ĕgitim Dergisi, 26(5), 1395-1406. https://doi.org/10.24106/kefdergi.1848

Salmela-Aro, K., Kiuru, N., \& Nurmi, J. E. (2008). The role of educational track in adolescents' school burnout: A longitudinal study. British Journal of Educational Psychology, 78(4), 663-689. https://doi.org/10.1348/000709908X281628

Salmela-Aro, K., Kiuru, N., Leskinen, E., \& Nurmi, J. E. (2009). School burnout inventory (SBI) reliability and validity. European Journal of Psychological Assessment, 25(1), 48-57. https://doi.org/10.1027/1015-5759.25.1.48

Schumacher, R., \& Lomax, R. (2004). A beginner's guide to structual equation modelling. London: Lawrence Erlbaum Associates, Publishers. https://doi.org/10.4324/9781410610904

Seçer, İ. (2015a). Üniversite öğrencilerinde okul tükenmişliği ile psikolojik uyumsuzluk arasındaki ilişkinin incelenmesi. Atatürk Üniversitesi Sosyal Bilimler Enstitüsü Dergisi, 19(1), 81-99.

Seçer, İ. (2015b). Okul tükenmişliği ile akademik güdülenme arasındaki ilişkinin yapısal eşitlik modeli ile incelenmesi. Journal of Research in Education and Teaching, 4(1), 424-433.

Seçer, İ. (2016). Üniversite Öğrencilerinde Okul Tükenmişliği ile Psikolojik Uyumsuzluk Arasındaki İlişkinin İncelenmesi. Atatürk Üniversitesi, Sosyal Bilimler Enstitüsü Dergisi, 19(1), 81-100.

Seçer, İ., Halmatov, S., Veyis, F., \& Ateş, B. (2013). Okul tükenmişlik ölçeğinin Türk kültürüne uyarlanması: güvenirlik ve geçerlik çalışması. Turkish Journal of Education, 2(2), 16-27. https://doi.org/10.19128/turje.181057

Seçer, İ., Veyis, F., \& Gökçen, R. A. (2015). Eğitim stres ölçeğinin Türk kültürüne uyarlanması: güvenirlik ve geçerlik çalışması. Illkögretim Online, 14(1), 216-229. https://doi.org/10.17051/io.2015.15313

Sedere, U. M. (2010). Towards a Stress Free Education: International Perspective. Online Submission.

Sun, J., Dunne, M. P., Hou, X. Y., \& Xu, A. Q. (2011). Educational stress scale for adolescents: development, validity, and reliability with Chinese students. Journal of Psychoeducational Assessment, 29(6), 534-546. https://doi.org/10.1177/0734282910394976

Vasalampi, K., Salmela-Aro, K., \& Nurmi, J. E. (2009). Adolescents' self-concordance, school engagement, and burnout predict their educational trajectories. European psychologist, 14(4), 332-341. https://doi.org/10.1027/1016-9040.14.4.332 